\title{
THE LIBERATION PRAXIS OF DISABILITY THEOLOGY WITHIN THE APOSTOLIC FAITH MISSION OF ZIMBABWE: A CHRISTIAN THEOLOGICAL PERSPECTIVE
}

La praxis liberadora de la teología de la discapacidad en la Misión de la Fe Apostólica de Zimbabue: una perspectiva teológica Cristiana

\author{
Nomatter SANDE ${ }^{\mathrm{I}}$ \\ JOHN RINGSON ${ }^{2}$
}

\section{Abstract}

Despite the inter-disciplinary inclusivity of Disability Studies in the globe over time, the religious organization's systems are still repulsive to accept the physical and psychosocial realities of people living with Disabilities. The growing literature that should be influencing religious perspectives about people with disabilities has not been able to extricate the dogmatic stereotypes and myths associated with Disability. As such, the prevalence of the diverse responses Disability from different contexts has compromised the ideological and material investment in Disability Studies. We used the combination of phenomenological observation and informal conversation qualitative methodologies to establish the experiences, feelings and behaviors of the Apostolic Faith Mission of Zimbabwe (AFMZ) congregants in Harare on the impact of the liberation praxis of Disability Theology. The findings showed that people with disabilities are most often marginalized, excluded and discriminated against

1 Holds a PhD in Religion and Social Transformation. He is affiliated to Apostolic Faith Mission International Ministries, United Kingdom. E-mail: pastornomsande@yahoo.com

$2 \mathrm{PhD}$ in Governance and Community Development. Post-Doctoral Research Fellow at the University of Johannesburg, South Africa. E-mail: jringson@gmail.com 
and perpetually subjugated within the religious circles. This complexity of disabilities is exacerbated by the fluidity of policies, culture and religious ideologies when dealing with issues of disabilities. In conclusion, this study emphasized that Disability Theology within Christian tradition should function as a liberating praxis when dealing with issues of disabilities and being effectively used to enhance the participation of people with disabilities in all the religious liturgical activities.

Keywords: Disability; Liberation Praxis; Contextual Theologies; Christianity; Zimbabwe.

\section{Resumen}

A pesar de la inclusividad interdisciplinaria de los estudios sobre la discapacidad a lo largo del tiempo, los sistemas de las organizaciones religiosas son todavía reacios a aceptar las realidades físicas y psicosociales de las personas en condición de discapacidad. La creciente literatura que debería influir en las perspectivas religiosas sobre las personas en condición de discapacidad no ha sido capaz de desmontar los estereotipos y mitos dogmáticos asociados a la discapacidad. Así, el predominio de diversas respuestas en relación con la discapacidad desde diferentes contextos ha comprometido la inversión material e ideológica en los estudios sobre la discapacidad. En el trabajo se combinó la observación fenomenológica con la conversación informal de los métodos cualitativos para caracterizar las experiencias, sentimientos y comportamientos en relación con el impacto de la praxis liberadora de la teología de la discapacidad de los miembros de la Misión de la Fe Apostólica de Zimbabue en Harare. Los resultados revelan que las personas en condición de discapacidad son marginalizadas, excluidas, discriminadas y subyugadas con mayor frecuencia en los círculos religiosos. Esta complejidad de las discapacidades es exacerbada por las políticas, la cultura y las ideologías religiosas relacionadas con las discapacidades. En conclusión, el trabajo enfatiza que la teología de la discapacidad dentro de la tradición cristiana debería funcionar como una praxis liberadora al tratar con asuntos relacionados con la discapacidad y ser utilizada para aumentar la participación de las personas en condición de discapacidad en todas las actividades litúrgicas religiosas.

Palabras clave: Discapacidad; Liberación; Praxis; Teología Contextual; Cristianismo; Zimbabue.

\section{Introduction}

The Apostolic Faith Mission in Zimbabwe (AFMZ) Church is the mother of Pentecostalism in Zimbabwe (Hwata, 2005; Sande, 2019). As a unified denomination, the AFMZ celebrated its 100 years of active ministerial engagement in 2010 before it was subsequently rocked by conflicts that have recently split the mother of Pentecostalism in Zimbabwe into two diametrical entities in 2018. Chivasa (2018, p. 3) indicated that before the split of the AFMZ, its membership is over two million. During the AFMZ's over 100 years of existence, it has reproduced many Pentecostal churches which replicated its religious liturgical systems in one way or the other. While the AFMZ exponentially grew in terms of numbers and adherently upholding its religious dogma for many years, Hwata (2005) argued that AFM does not do well in terms of embracing the socio-economic dimension of the gospel. Instead, the AFM International 
(AFMI) ideological, religious thrust since its inception in 1908 in South Africa was on repentance, holy spirit baptism and second coming of Jesus Christ (Burger and Neil, 2015). Arguably, it can be that the mother of Pentecostalism neglected the socio-economic dimension of the gospel that includes but not limited in building schools, hospitals and orphanage centers and the social well-being of people. Considering the longevity of the existence and growth of the AFM, it makes the exploration of the impact of the liberation praxis of Disability Theology within the religious organizations in Zimbabwe appropriate.

Up to this date, several works have shown the plight of people with Disability within the international development community. More than $80 \%$ or around one billion people with Disability live in third world countries, where they encounter material hardships and social exclusion (Chouinard, 2015). Despite concerted efforts and investments, people with Disability remain mostly invisible in their communities and developmental activities. It is against this backdrop that religious communities are strategically positioned to promote an understanding of the need to concentrate on people with Disability, while their myths and stereotypes repulsively dispel the understanding of the physical and psychosocial realities of people living with Disability. A study by Goldstein and Ault (2015) offered a comprehensive empirical analysis of global perspectives on Disability. It notes a gradual appreciation of the inclusion and participation of people with Disability in the educational, vocational, recreational and residential sectors. Almost every academic paper on global perspectives on Disability includes a section relating the inclusion of people with disability in society. Accordingly, this study proposes that the liberating elements within the Disability Theology are resources for meeting the needs of people with Disability despite the prevalence of some invincible religious myths and stereotypes portrayed against people with Disability. Saltana (2014) stated that, recently, disability issues have begun to be addressed as mainstream developmental issues rather than a matter of separate programs and charity.

Disability is notoriously tricky to define (Sande, 2019), and there is a growing body of literature that deals with definitions of Disability. The first systematic framework on the equalization of people with Disability was reported by the United Nations Equalization of Opportunities for people with Disabilities Information in 1994. It encouraged measures for equal participation by people with Disability in faith-based communities. The Convention on the Rights of people with Disability (CRPD) of the United Nations (2006) notes that Disability appears for two reasons: the associations between people with Disability and the hindrances that impede their collaboration in the community. All the elements presented in the CRPD mentioned above support the hypothesis that people with Disability are marginalized. The policies introduced in this Convention suggest that there is room for integrating people with Disabilities in society. While the affirmations contained in the CRPD study are useful and add information to this study, there is insufficient data on the material from diverse religions, especially on how theological responses can challenge the oppression and marginalization of people with Disabilities. This study explores the liberation praxis of Disability Theology from a Christian theological perspective within the AFMZ in the selected congregants in Harare, Zimbabwe, using the phenomenological observation and informal conversation qualitative methodology. The main research question of the study is; why is it difficult for religious organizations to embrace the Liberation Praxis of Disability Theology, despite the investment and emphasis that has been put on it internationally and locally?

The study commences by introducing the context of the study on liberation praxis Disability Theology within the AFMZ in Harare, Zimbabwe. Accordingly, this was followed by the conceptualization of 
Disability in three folds as a stand-alone concept, Disability Theology and Disability as a Christian perspective. Further, we conceptualized the religious myths and stereotypes associated with Disability as part of the literature review of this study. The article also explains the phenomenological observation and informal qualitative methods, data collection and analysis methods in its methodological approach. Subsequently, data was presented data and discussed because of two key thematic areas: the understanding of the theology of the cross and sufferings theologies. Lastly, we discussed the implications of the study on the gospel of social transformation.

\section{An overview of Disability Theology}

It is essential to understand how Christian theology perceives Disability. In this study, the authors select a few scriptures and Christian theologians who have been central to this discussion. This study uses John Swinton's definition of Disability Theology. According to Swinton (2011), Disability Theology is an attempt by both people with Disability and people without disability people to comprehend the biblical, anthropological and theological positions about Disability, proffering a voice to the experiences of people with Disability. Disability Theology is a recent development, and the philosophical premise of this theology is anchored in analyzing practices of preaching, religious education and biblical interpretation. Disability Theology is an unfolding academic discipline relatively new to theological studies (Richie, 2015). In the same line of thought, Swinton (2011) argued that Disability Theology is a multi-disciplinary analysis benefitting from insights of disciplines such as Theology, Philosophy, Anthropology, and Sociology. Hence, the entry point of Disability Theology is the notion that Disability is a stable element of life that warrants theological reflection. Vermeer (2014) argued that Disability Theology is a process that involves innovative ways of listening to and reflecting on people with Disability.

What is interesting is that Disability Theology is developed against the background of marginalisation of people with Disability in the context of religion. In other words, Disability Theology functions as the basis for appreciating human difference by allowing the participation of people with Disability (Eiesland, 1994). It is possible to view Disability Theology as a framework with the ability to promote unity embodied solidarity and re-symbolization. Thus, participation is enhanced within Disability Theology, as put by Creamer (2012), that Disability Theology explores the engagements or (failures) of religious traditions on issues of Disability and impairments for the construction of possible inclusive theological work. Thus, in the light of the inter-disciplinary nature of Disability Studies, Disability Theology provides lenses for analyzing and interpreting the experiences of people with Disability in the light of Christian tradition. The experiences of people with Disability must be juxta-positioned with significant elements of human life deserving theological reflection. If this notion is anything to go by, then there is no single approach that satisfies Disability Theology, considering the various settings and styles or kinds of theologies within the diverse religions of the world.

However, fundamental roles can fuel insightful theological reflection about Disability. Besides, it furthers the conviction that the experiences associated with Disability are right, and supports the vow to do justice for people with Disability. Therefore, a healthy relationship between Christian theology and Disability is essential, since this can help understanding the plight of people with Disability. Furthermore, 
this resonates with Ndlovu (2016), who argued that the goal of Disability Theology should be to change the church and society and to set up strategies, laws, decisions and programs that confirm, secure the God-given right of people with Disability of equal access to social, economic and spiritual resources, opportunities and activities in all areas of life.

Why would Disability need a Disability Theology? The purpose of theological inquiry is to provide a necessary voice to people within faith communities. As it was noticed by McReynolds (2016), Disability is a crisis that has no end. In other words, this scholar perceives Disability as a permanent negative experience, implying that there seems to be no point in the life of people with Disability, nor positive life experiences can be witnessed. An insight by Brock (2012) is critical when he asserted that "the discourse of disability cannot be only a discourse about politics or Disability Studies, because it raises wide-ranging questions for constructive practical and dogmatic theology" (p. 9). Therefore, Disability Theology opens the room to question on how the experiences of people with disability affect families, churches and their communities. Within this framework, it is possible to assume that Disability Theology underscores the notion that the role of Christianity is supporting people with Disability because they are facing a lifelong crisis. Therefore, the unique voice of Christian Disability Theology is enhancing the church to take responsibility for people with Disability. Assuming responsibility for people with Disability means that "the church should be open to the people with disabilities to fulfil its call to take care of the disadvantaged and vulnerable" (Basselin 2011, p. 48). Hence, to validate this argument one of the tasks the church and theologians have is to be responsible of people with Disability. "This responsibility does not involve the 'altar call' and 'laying on of hands' on the lame, blind and deaf, among others, but includes accepting and creating space, an enabling environment for people with Disability in which to feel secure, acknowledged and to be viewed as normal human beings" (Sande, 2019, p. 6). For instance, Eiesland (2002) noted that the church traditionally had adopted demeaning attitudes towards people with Disability. She recognises that these views emanate from the interpretation of some biblical texts, which seem to suggest that physical Disability is a distortion of the image of God.

Christian Disability Theology places emphasis on justice for humanity. By doing so, ecumenical movements should embrace Disability as part of the human experience in this life. Because of this, the emergence of Disability Theology is a bonus for churches, which has, for several decades, viewed Disability from a deficit model. Following intentional consideration for justice for all humanity, Disability Theology can help to discourse openly on comfort zones, perceptions, attitudes and practices of modern Christendom to consider accommodating people with Disability as human beings. Another prominent issue emerging from the description of Disability Theology is that Disability Theology can challenge Christian theology on Disability, which holds that prayers must cure people in the church with Disability (Basselin 2011). For this study, Disability Theology provides the theoretical foundations for basic legitimate principles that should be respected when dealing with people with Disability. It is critical to pursue Disability Theology, since it helps to acknowledge that Disability is a reality and is a constant reminder that all human beings are vulnerable and dependent. This concern is crucial for this analysis, bearing in mind that vulnerability does not only mean being susceptible to harm but also to kindness, joy and fulfilment. Therefore, Disability Theology states that real humanity is not only limited to the cult of normalcy, but vulnerability is also part of being human. Such feelings must not be regarded as lesser or inferior, as it can teach the church to acknowledge its weakness, thereby removing a sense of insecurity and exclusion against people with Disability. 
This study supports the thrust of Disability Theology, of compelling every individual to accept that Disability can be experienced at any level and by any person, notwithstanding age, race or status. For instance, the vulnerability of human beings towards Disability suggests that every individual can experience Disability despite having sinned or not. Thus, Disability Theology portrays the extent of discrimination of people with Disabilities, whereas being people without Disability should be treated as a mean to an end everyone should be treated as heading for Disability. Since it can be said that Disability is a social construct based on cultural beliefs, then Disability Theology gives this analysis the idea that people with Disability are vulnerable to stigma and discrimination. Disability Theology recognises the alienation and exclusion suffered by people with Disability. However, it continues discussing that there is a need to address these social problems, and the church is one of the institutions that are better situated to address the alienation and exclusion suffered by people with Disability (Basselin, 2011). Thus, Disability Theology seeks community transformation, and the church is part of the community. This theology is a deliberate shift from viewing Disability as a 'tragedy' that requires a solution to considering Disability as a part of being human, a state that calls for support and care. It asks the church to embrace transformation and movement beyond the binary (normal vs abnormal), and to embrace the notion that all human beings have in common vulnerability (Reynolds, 2012). Such an approach lays down the philosophical framework for understanding the experiences of people with Disabilities, and use it to formulate ethical ideas for developing an appropriate theological response to the needs of people with Disability.

\section{Disability Theology in Christian perspective}

In order, to apply Disability Theology within a Christian perspective, this study grapples with the following critical aspects of Christian tradition namely: first, 'the theology of the cross'; and second, 'the theology of suffering' as discussed in detail below. This study acknowledges that it is evident that some Christian doctrines are more relevant than others, but this study, the theology of the Cross, and the theology of suffering are connected to Disability Theology. As such, it is possible that pursuing these two to enhance the understanding of Christian theological perspective towards responding to people with Disability. Thus, taking Disability Theology as a function of liberating praxis exposes significant commonalities and divergences within religions. It could be argued that Christian liberation theology has useful paradigms and tools that can be adapted to enhance meaningful Disability Theology.

Issues about Disability, therefore, need to be interpreted with the role of theological paradigm in mind. Such a position is against the current moral understanding that Disability is a result of sin. A broader perspective has been adopted by Eiesland $(1994 ; 2002)$ who argues for a liberating theology of Disability that emancipates people with Disability. What is interesting is that taking liberation praxis of Disability Theology has the potential to make the church take responsibility for people with Disability positively. As noted by Eiesland $(1994 ; 2002)$, the church needs a liberation theology of Disability to transform the perception, from 'disability as a tragedy' to 'disability as part of being human'. It can, thus, be suggested that Disability Theology liberate people with Disability. However, Disability Theology must rely on other premises embedded within contextual theologies. Since Christian liberation theology focuses on destroying social, economic and political injustices, this implies that Disability and poverty are close associates. In developing nations, people with disability experience poverty more than people without Disability. Hence, 
within this framework, the liberation praxis of theology accepts the weakness and vulnerability of people with Disability. Correspondingly, this is opposed to the approach of Christian contextual theologies which focus mostly on fixing the situation of the poor and oppressed people. Consequently, although Christian contextual liberation theology acknowledges that God is on the side of the oppressed, it does not position God as someone vulnerable to oppression.

While the literature on Disability and Christian theology shows that there is much in terms of the time, resources and effort that have been invested in the liberation praxis of Disability Theology in the globe, there is still a piece of overwhelming evidence the religious myths and stereotypes that the people with Disability are still grappling within religious circles. Etieyibo and Omiegbe (2016) pointed out that people with mental illness are being killed and discriminated based on religious and cultural beliefs on Disability. In the similar view, Ringson (2018) in his study on the misconception of children living with albinism as a form of Disability in Zimbabwe, overwhelmingly found out that religious and cultural organizations predominantly perpetrate most of the stigma and discrimination of people living with Disability. Etieyibo and Omiegbe (2016) and Ringson (2018) studies concur that superstitiously most of the religious organization's belief, especially Pentecostals, are wielding a belief that they go to church for healing and deliverance. In that regard, the theology and religious dogma of such organizations do not associate Disability as a natural physical impairment life that one ought to positively live with it. Instead, there is a common misconception in these prevailing and mushrooming prophetic, charismatic and Pentecostal religious organizations that people living with Disability have been either cursed, bewitched or possessed by the evil spirit. It is there in that premises that most of the people living with Disability if they prayed for ones and not getting healed or delivered will attend either church the religious organization, go to the streets to beg for food or staying at home. Etieyibo and Omiegbe (2016) assert that it is widespread to find people with Disability begging for food in the streets while the church is packed with people without Disability. Consequently, predicated in that, it can be safely said that religious beliefs stigmatize, discriminates and scare away people with Disability from their organization by not correctly implementing the liberation praxis of Disability Theology.

\section{Methodology}

This study is a combination of a phenomenological observation and informal conversation qualitative research methods that seek to establish the experiences, feelings and behaviors of the AFMZ congregants on the efficaciousness of the liberation praxis of Disability Theology within the three selected congregations in Harare, Zimbabwe. A phenomenological qualitative design was invented and developed by Husserl (1970), and its main thrust focusses on the lived experiences or life-world as the unit of analysis to understand human behavior. Freeby (2013 p 62) defined phenomenological observation as the process of observing events, people, processes and objects. Freed further assert that the phenomenological observation process involves the observer's avoidance of prior prejudices, opinions, associative memories, filtering mechanisms and dogma to those observations. Given the above, the researchers were part of the church organization together with their families, and hence they had extensive opportunities to observe all the proceedings how the liberation praxis of Disability Theology was handled within the church proceedings. The researchers 
being active members of the AFM are not writing from abstraction, but rather authoritatively from the organizational experiences.

To complement the phenomenological observation, the researchers undertook informal conversations with the ten key role players within the AFM three selected congregants such as the church elders, deacons, pastors and members of which six were male, and four were female. The ages of the respondents' range between 30 and 70 years. The first informal conversations that triggered this study occurred during an informal after church leaders' seminar discussion on the church policy and people living with Disability, which the authors followed up later for more details and research. In the premises of the preceding, both the informal discussions and phenomenological observations focused primarily on two sub-questions: the first sought to understand whether the key role players (church, elders, deacons, pastors and active members) had ever heard about the liberation praxis of Disability Theology with their organization; and the second sought to understand the religious rights of people living with Disability and the conventional best practices of achieving them within their organization?

All the conversations with the key role players were conducted in their specific indigenous language. After each discussion and observations, the researchers would take pains to document the observations and discussions while they were still fresh within their memories. The combination of these two qualitative methods (phenomenological observations and informal conversations) enriched this study because its findings took the researchers' memories back to their childhood experiences as they were growing in an organization until the time this study was undertaken. The most recent studies conducted by Swain and Spire (2020) and Ringson and Chereni (2020) proved that the combination of the phenomenological observation and informal discussions enriches qualitative studies combined better than using one.

The inclusion selection criteria for the participants was purposive sampling approach as Patton (1990) asserts that purposive sampling is the best method used with a small number of individuals/groups which may well be sufficient for understanding human perceptions concerning the social phenomenon under study. In the similar view, Tongco (2007, p. 147) argue that in purposive sampling, it is the researcher who decides what need to be sampled and who can appropriately and relevantly provide the information required for the study. Thus, in that premises, the inclusion criterion of the participants in the informal conversations was purposively sampled on the basis that they were AFMZ bona fide elders, pastors, deacons and church members actively holding decision making positions within their congregations. To protect the dignity and confidentiality of the respondents, the researchers devised a coding system which represents the gender and age of the respondent. For example, F1, 30 years refers to the first female respondent aged 40 years or M2, 60 as the second male respondent aged 60 years, F9, 50 years and M10, 65 years and above. This study was therefore sporadically and intermittently conducted over three years between the year 2014 and 2016 within the selected AFMZ congregants in the Harare area of Zimbabwe

The data collected were analyzed using the model of thematic analysis suggested by Braun and Clarke (2006). Braun and Clarke argue that thematic analysis provides an accessible and theoretically open-coding approach to analyzing qualitative data. This involved familiarization with the data, reviewing themes and refining themes. The trustworthiness (according to Lincoln \& Guba 1985) of the study was enhanced by triangulation of the phenomenological observations, informal discussions and different data sources, using purposive sampling and providing a detailed description of the methods used. The data were therefore 
presented within the two main themes that emerged after a thorough scrutiny of the data, namely, the perceptions on the Disability Theology of the Cross and the perceptions on the Disability Theology of suffering. Nancy Eiesland, one of the most prominent proponents in the Disability Theology of the Cross and the Disability Theology of the Cross, is going to be used as a benchmark in discussing the findings of the from the phenomenological observation and the informal discussions. The findings of the study were discussed in the two themes mentioned above and the literature which constitute both the theory, secondary data and scriptural linkages to the study

\section{Discussion of the findings}

\section{Perceptions and views on the Disability Theology of the Cross}

In order to make the Christian liberation theological praxis function in the context of people with Disability, there should be deliberate theological reflections. For instance, this study asks the theological understanding, which is brought by the 'theology of the cross' in the context of people with Disability. The experience of Jesus on the Cross, according to Christian liberation theologians, was a sign of his identifying with the vulnerable, but the resurrection presents Jesus as overcoming evil and suffering. In other words, Christian liberation theology presents a God who is powerful but has identified himself with the poor, weak and oppressed. From this perspective, this study argues that Christian liberation theology is based on triumphalist theology.

As a matter of inference, Christian liberation theology is regarded as double-edged in this case, considering the number of cases of marginalization and discrimination of the people with Disability from the religious circles in Zimbabwe. In the same vein, liberation disability praxis theology can use this approach. For instance, while the pastoral ministry in the church may claim the victory of the Cross (healings to people with Disability), it must also identify itself with those people with Disability who are not healed or whose needs are not met. Between the period 2014 and 2016, we observed a lot of the pastors, members and lay-leaders that shows that Disability Theology informs of the liberation praxis of Disability Theology was lacking in practice within the AFMZ three selected congregants in Harare, Zimbabwe. Overwhelmingly, we discovered the following in summary which does not add up the understanding of the liberation praxis of Disability Theology: the preachers seldom speak about people with Disability; the church does not have a wheelchair entrance into the church hall; the gospel preached mainly talks about deliverance and evil spirits, and there are members with Disability. We could only see a few who would visit when they see adverts in the billboards, flyers and posters which emphasize healings and deliverance.

As observers and researchers, we discovered that the disabled people who were attending some church services in wheelchairs were not being healed as preachers declared despite the declarations that they had been healed. This approach repeated over and over in our presence, and they were no practical engagement of the Pastors with the people with Disability. This approach of preaching has become so contagious to the extent that even the young preachers and those who plant their ministries, they brand their ministries along with deliverance and healing. Because of Disability Theology, Nancy Eiesland visualizes new symbols for God, which show Him as disfigured on the Cross and disabled. Following the effects of Eiesland's 
argument, what people with Disability are experiencing now will be a credible image when looking at a Jesus with crucifixion scars in the next life. Writing back from a sociological viewpoint, Eiesland sees her work as liberation theology, challenging the beliefs of the congregation that a flawless body speaks to the wholeness of the spirit. She advises that the focus must not be on the physical modifications of their space, but that people with Disability must have the same choices as people without Disability. In our informal discussions, we discussed with some of the critical role players in the church (M2- 60 years; F1-40 years; M3-49; F4-45) in our discussions shared the view that as a member of the church, they understand and know Disability and their conventional rights from the organizations outside the church and the government and not from the church. In the church, we emphasize healing, and we are taught that the devil causes disability. They further indicated that they do assist people with Disability, but their assistance does not interfere with their dogmatic that Disability is not from God but rather a curse from the devil. While as human beings, we may live with Disability, but it is not from God but the devil.

It is clear from the previous excerpt that the theology of Disability has not yet sunk in the systems of the religious organizations as long as people with Disability are not comfortable fellowshipping in these Pentecostal churches. The reason why these religious organizations fail to grasp the Disability Theology their belief in all-powerful God who cannot be conquered with the physical challenges. In this view, Basselin (2011) emphasised that the vulnerability, weakness and brokenness of God is a dimension hidden from every human being because people prefer a mighty God who conquers weakness. This line of thought provides this study with how people with Disability can be accepted in the church. Liberation disability praxis theology challenges triumphalist theologies which portray Disability as abnormal and requiring a mighty God to change the fortunes of the disabled. Overall, liberation disability praxis theology acknowledges the strength that lies in brokenness-disability as opposed to Christian contextual liberation theology which seeks for the extraction of the weak and oppressed from suffering and vulnerability. It can be noted that this study embraces Paul's expression of lived experiences of Disability as the basis of a theology of Disability in 1 Corinthians:

But God chose the foolish things of the world to shame the wise; God chose the weak things of the world to shame the strong. God chose the lowly things of this world and the despised things-and the things that are not-to nullify the things that are, so that no one may boast before him (1 Corinthians $1^{27-28}$ ).

Although this biblical text does not directly address issues of Disability but, using the Disability Theology lens, the current study concurs with Paul. An implication of this is the possibility that the Christian theology should move away from the perspective that Disability renders the person experiencing it helpless, weak and deficient. Instead, people with Disability should be considered as normal human beings (Quinn et al. 2002). This is in case, at least in part, because the crucified, dead and resurrected Jesus is a reference point that brokenness does not suggest helpless, weak and deficient. The notion of equality between people with Disability and people without Disability plays a significant role in disability discourse. As Coleridge (1993) puts it, people without Disability must regard themselves as temporarily able-bodied. Disability distorts perceptions about human equality.

Further, Reynolds (2008) cited in Basselin (2009:1) argued that "disability is a profound symbol of human brokenness" (2008). Disability Theology helps the church to view Disability as a symbol of humanity's vulnerability to brokenness. This idea by Reynolds can be convincingly used in this analysis to 
argue for the centrality of all human life in the missional approach of the church. However, viewing this brokenness should not be negative but a sign of humanness and solidarity with Jesus on the Cross. Basselin (2011) refers to the example of Jesus on the Cross as the basis of human vulnerability and dependence. She submits that Jesus on the Cross is a symbol of a disabled God, as propounded by Eiesland (1994). In her argument, Basselin stated that Jesus on the Cross is a classic example of a God who identifies with his people through the vulnerability of suffering. Hence, the death and resurrection of Jesus is a symbol of God broken for his people. Thus, Basselin (2011) emphasised that "Christ as disabled is the starting point for any theology of disability". The point that Disability Theology is making is accepting Disability as a normal human experience and, therefore, a reality of life. This aspect is central to this analysis, as it provides a political principle to include the human rights of people with Disability Theology and liturgical praxis.

Thus, liberation disability praxis theology can correct these distortions about human equality by using a theology from the margins. For people with Disability, theology from the margins focuses on the lived experiences rather than the Biblical representation of people with Disability which mostly is disabling. Hence, this present study raises the possibility that the liberation disability praxis theology, which comes from below has the potential to meet the needs of people with Disability. The result, then, is that the liberation disability praxis theology goes beyond the Christian contextual theology which focuses on disrupting the institutionalized socio-economic and political vices of the people (Avila 2010) but start with the experiences of people with Disability. When this happens, the liberation disability praxis theology entails moving from orthodoxy to orthopraxis. In short, regardless, of the social, economic and political challenges, the freedom of people with Disability is connected to practical engagement of their lived experience.

In the positive vein, the emancipation of people with Disability underscores the notion that inner'personal salvation' is essential that the outer - 'inclusion or equality of bodies'. The focus of outer'inclusion or equality of bodies' is done as a coping strategy for legitimizing equality in public worship. When inequality is recognized and challenged on the base of equality of soul and spirit than bodies, the liberation disability praxis theology can provide reconciliations as a primary dimension of their praxis. As Otieno (2009) stated, Eiesland's (1994) liberation theology is about justice and the inclusion of people with Disability. As with the case within Christian contextual liberation theologies, the Christian theological perspective of Disability can provide powerful tools for creating communities of worship based on justice and reconciliation. Thus, Disability Theology as a 'praxis theology', focusing on transforming the Christian theological perceptive about Disability and begin to meet the needs of people with Disability. Disability Theology must then be developed among people with Disability as they struggle for their freedom. In this sense, Disability Theology, practice and reflection cannot be separated, even different diverse Christian traditions.

Further, the Pentecostalism theology of the Cross is critical to this study. Warrington (2008) discusses the Cross in the light of Pentecostals and argues that the crucifixion emphasizes Jesus' triumph over sin, suffering and the devil. Thus, Jesus suffered so that believers are not required to suffer again. Furthermore, rather than focusing on the misery and the torment of the Cross, Pentecostals have settled on the glory related to triumph, making the Cross a triumphant story. From a positive note, the victory demonstrated by the Cross makes that people with Disability must not be content to accept that their ultimate fate but accept that their conditions are restored through divine healing. Within Pentecostal tradition healing, 
people with Disability is a symbol of the demonstration of the power of God. According to Sande (2019a, p. 4) "demonstrations of power must not disable people with disabilities, as shown by the social model of Disability. Nevertheless, an authentic theology of demonstration of power should foster a spirit of love and belonging, and create a caring community for people with disabilities".

To summarize the theology of the Cross, discussing the lived experiences of people with Disability without referring to the theology of the Cross would be an injustice, given that the theology of the Cross offers an opportunity to engage with the visible God in all his grandeur, suffering and wounds. Just as the axis of life for the people with Disability rotates on constant struggle and strife, so the centerpiece of the theology of the Cross is the torture, suffering and subsequent death of Christ Jesus on the Cross of Calvary. For the people with Disability, the theology of the Cross offers hopes as it states that it is in weakness that there is strength; and it is 'in death' that there 'is resurrection and life'. Therefore, it follows that it is in suffering that there is happiness, given that the Cross is the basis of Christian hope (Dickson, 1984).

\section{Perceptions and views on the Disability Theology of suffering}

We do not attempt to explain why there is so much suffering in the world, but to bring to the fore the reality of suffering as it relates to people with Disability. In this regard, this is what this what the observations and discussions found that people do not want and are not yet ready to accommodate the theology of suffering in any form. So, the theology of suffering is premised on the notion that suffering is inevitable, and that enduring is the key to achieving higher levels of spirituality or perhaps seeking grace and favor from God. That being said, Eiesland (1994) highlights the problems that emanate from a theology of suffering as presenting significant hindrances in the lives of people with Disability. In our observation as researchers on the understanding of the theology of suffering and Disability from the AFMZ congregants, we discovered that people only appreciate suffering if it leads someone to happiness, but if it is permanent, it is regarded as from the devil and not from God. In our informal discussions, we discussed the understanding of the liberation praxis in Disability Theology within the AFMZ and the critical role players in the church (F1-55 years; F5-60; M6-42; F7-45; M8-70) agreed that; they agreed that suffering does not come from God, and therefore prayers and deliverance need to free them; they also shared that even if we are not getting healed but we wat preachers that give us hope than those that tell the truth but demoralizing us.

In this case, 'suffering' makes people with disability passive and submit to all kinds of abuse in the bid to obey God. In particular, all humanity is prone to suffering. Hence, it is challenging to measure suffering, which can be said to benefit people with Disability. Even though Christian theology has ideas about enduring suffering but also superficially accepting of the concept of suffering disables people with Disability. According to Eiesland (1994), people with Disability become less visible, more voiceless than before and significantly marginalized due to the theology of suffering, which has taken center stage in their interactions in and out of the church. If we link the theology of suffering in the context of Disability, we can see that the need for redressing the biases directed at people with Disability. It is clear that in some ways, the theology of suffering has over the years helped people with Disability to cope with their condition.

Cuestiones Teológicas, Vol. 47, №. 107 (Enero-junio, 2020) | 89 
By contrast, suffering for God is not a contextual experience to be equated to other notions of contextual theologies like black and Latin American liberation theologies. Instead, the liberation disability praxis theology should refer to inward man yearning and suffering for a closer relationship with God than the physical suffering. Since Christian traditions are heterogeneous and their emphasis on the theology of suffering have a diverse impact on people with Disability. Consequently, society has preconceived ideas about people with Disability, one of which is that they must have committed some wickedness to deserve their fate, while the other is that they deserve their suffering while awaiting miraculous healing or death.

Applying these notions to this study means that the theology of suffering alters how believers perceive people with Disability. In order to see as clearly as possible, the relationship between the theology of suffering and Disability, further analysis is needed to critical to draw insights from the theology of suffering and Disability Theology to understand God's will with regards to suffering, illness, disease, healing and Disability. Keeping in view the importance of this topic, this study argues that the Christian theological perspective of Disability should develop the hermeneutical skill to interpret Scriptures like 2 Timothy 3:12, Mathew 8:19-20, Romans 8:17, Psalms 34:19, Acts 14:22, 1 Corinthians 15:19,31 since they are vital passages used in the theology of suffering. With regards to the theology of suffering, Eiesland (1994) aptly summarized it as virtuous suffering. While it may be true that people with Disability suffer in one way or another due to their limitations as well as the limitations of their living environments, disability theologians warn that conflating Disability and suffering can potentially paternalise, stigmatise and marginalise people with Disability in the same manner that conflating Disability and sin can.

In the context of Disability, therefore, the theological perspectives of Pauline suffering as evidence of God and grace as well as the remembrance of the suffering of the Cross as the bane of the disabled, need deconstruction and rethinking. The critical inference that one can make in this analysis is that both the theology of suffering and the theology of Disability helps Disability Theology to explore the lived experiences of people with Disability. Since, the theology of suffering discourse believes that all suffering should be endured for purposes of achieving higher levels of spirituality or perhaps seeking grace and favor from God, accepting this position hinders alternative perception about Disability. In general, internalizing discourses emanating from the theology of suffering make people with Disability become passive recipients of all kinds of suffering treatments from society. It is worth noting that the theology of suffering makes people with Disability surrender as a sign that they are obeying God silently.

Consequently, a poignant example is a part that people with Disability become less visible, more voiceless than before and significantly marginalized due to the theology of suffering, which has taken center stage in their interactions in and outside of the church (Eiesland, 1994). From the above, it must be noted that society has preconceived ideas about people with Disability, one of which is that they must have done something terrible to deserve their fate. What is surprising is that some explanation people with Disability are a suffering group who deserve their suffering while awaiting miraculous healing or death. A critical question to ask whether the suffering of people with Disability is because of the Cross or not? Those of us interested in these issue plunge into attempting to understand God's will with regards to suffering, illness, disease, healing and Disability. 


\section{Conclusion}

The overarching aim of this study was to explore the impact and efficacy of the liberation praxis of Disability Theology from a Christian theological perspective. The study identified that Christian theology perspective has an ambivalent impact on Disability. As such, this study has explored the merits that support Disability Theology as an appropriate theoretical framework for analyzing and interpreting the experiences of people with Disability in the light of Christian tradition. Thus, Disability Theology enables both people with Disability and people without Disability Christians to engage the Gospel, God and humanity in the light of people with Disability, thereby giving voice to the diverse theological meaning of the human experience of Disability. While those as mentioned above must be the underlying reality, but this study has overwhelmingly established that religious myths and stereotypes of people with Disability caused the religious organizations ambivalent in accepting the liberation praxis of Disability Theology. In particular, the study used the theology of the Cross and the theology of suffering as underpinning to establish how the liberation praxis of Disability Theology can be applied. In conclusion, religious organizations must participate in the multi-stakeholders' programs for Disability so that they can fully understand that Disability is only about the evil spirit. However, a social reality that requires positive engagement and the best can be drawn out of the people with Disability.

\section{References}

Avila, M. (2010). Liberation," in Dictionary of Mission Theology: Evangelical Foundations. Illinois: InterVarsity Press.

Basselin, T. (2011). Why Theology Needs Disability. Theology Today, 68(1):47-57. https://doi. org/10.1177/0040573610394925

Burger, I. \& Nel, M. (2008). The fire falls in Africa, Vereening: Christian Art.

Blair, W. D. (2003). Christian Theology and Human Disability: A Literature Review. Journal of Religion, Disability and Health, 7(3):69-79. https://doi.org/10.1300/J095v07n03_06

Braun, V. \& Clarke, V., (2006). 'Using thematic analysis in psychology', Qualitative Research in Psychology 3(2), 77-101. https://doi.org/10.1191/1478088706qp063oa

Brock, B. (2012). Introduction: Disability and the quest for the human. In B. Brock \& J. Swinton (Eds.), Disability in the Christian tradition: A Reader (pp. 1-23). Grand Rapids, MI: Eerdmans.

Chivasa, N. (2018). Instituting dispute resolution procedures in the Apostolic Faith Mission in Zimbabwe church, In Die Skirling (Online), 52 (1), 2018. https://doi.org/10.4102/ids.v52i1.2285

Chouinard, V. (2015). Contesting Disabling Conditions of Life in the Global South: Disability Activists' and Service Providers' Experiences in Guyana. Disability and Society, 30(1), 1-14. https://doi.org/10.108 0/09687599.2014.986565

Coleridge, P. (1993). Disability, Liberation, and Development. Oxford: Oxfam. https://doi. org/10.3362/9780855987053

Creamer, D. B. (2012). 'Disability Theology'. Religion Compass, 6(7):339-346. https://doi.org/10.1111/j.17498171.2012.00366.x 
Dickson, K. A. (1984). Theology in Africa Maryknoll. New York: Darton, Longman and Todd.

Eiesland, N.L (1994). The Disabled God: Toward a Liberatory Theology of Disability. Nashville: Abingdon Press.

Eiesland, N.L (2002). 'Encountering the Disabled God'. The Other Side. 38(5):10-15. Recovered from :http:// www.dsfnetwork.org/assets/Uploads/DisabilitySunday/21206.Eiesland-Disabled- God.pdf.

Etieyibo. E and Omiegbe. O. (2016). Religion, Culture and Discrimination against persons with disabilities in Nigeria, African Journal of Disability, 5 (1), 192. https://doi:10.4/02/ajod.v5i1.192

Fast, M. S. (2011). A Theology of Disability: Living as a Theologian of the Cross. Journal of Religion, Disability and Health, 15(4):414-430. https://doi.org/10.1080/15228967.2011.620392

Freeby, R., (2013). 'A phenomenological observation of two theatrical learning environment', PhD thesis in educational leadership, Kansas State University, Kansas

Gillibrand, J. (2009). Disabled Church-disabled Society: The Implications of Autism for Philosophy, Theology and Politics. London: Jessica Kingsley Publishers.

Goldstein, P. and Ault, M. J. (2015). Including Individuals with Disabilities in a Faith Community: A Framework and Example. Journal of Disability and Religion, 19(1):1-14. https://doi.org/10.1080/23312521.201 5.992601

Husserl, E., (1970). The crisis of European sciences and transcendental phenomenology: An introduction of phenomenological philosophy, transl. D. Carr, North-Western University Press (Original work published 1936), Evanston, IL.

Hwata, B. (2005). An investigation of different phases of Pentecostal experience in the Apostolic Faith Mission (AFM). Pretoria: University of South Africa.

Lincoln, V.S. \& Guba, E.G. (1985). Naturalistic inquiry, Sage, Beverly Hills, CA. https://doi.org/10.1016/0147$1767(85) 90062-8$

Mcnair, J. (2007). Christian Social Constructions of Disability: Church Attendees. Journal of Religion, Disability and Health, 11(3):51-64. https://doi.org/10.1300/J095v11n03_05

Mcreynolds, K. (2016). The Gospel of Luke: A Framework for a Theology of Disability. Christian Education Journal, 13(1):169. https://doi.org/10.1177/073989131601300111

Miles, R. (1996). Rebecca S. Chopp and Mark Lewis Taylor, eds., Reconstructing Christian Theology. Journal of Religion, 76:657-658. https://doi.org/10.1086/489890

Ndlovu, H. L. (2016). African Beliefs Concerning People with Disabilities: Implications for Theological Education. Journal of Disability and Religion, 20(1-2):29-39. https://doi.org/10.1080/23312521.2016. 1152942

Otieno, P. A. (2009). Biblical and Theological Perspectives on Disability: Implications on the Rights ofPersons with Disability in Kenya. Disability Studies Quarterly, 29(4). https://doi.org/10.18061/dsq.v29i4.988

Patton, M.Q. (1990). Qualitative Education and Research Methods (2nd ed). Newbury Park. Sage Publications.

Reynolds, T. E. (2008). Vulnerable Communion: A Theology of Disability and Hospitality. Brazos Press.

Reynolds, T.E (2012). Theology and Disability: Changing the Conversation. Journal of Religion, Disability and Health.16:33-48. https://doi.org/10.1080/15228967.2012.645612 
The Liberation Praxis of Disability Theology within the Apostolic Faith Mission of Zimbabwe: A Christian Theological Perspective

Richie, C. (2015). Do Not Hinder Them: Educating Children with Mental Disabilities in the Church. International Journal of Children's Spirituality, 20(2):72-85. https://doi.org/10.1080/1364436X.2015.1030593

Ringson, J. (2018). Misconceptions associated with children living with albinism: Evidence from the Gutu District, Zimbabwe, African of Social Work and Social Development, 30 (2), 1-17. https://doi:10.2519/2415$5829 / 4061$

Ringson, J. \& Chereni, A. (2020) 'Ritual, myth and transnational giving within the Zimbabwe Assemblies of God Africa in Johannesburg, South Africa', HTS Teologiese Studies/Theological Studies 76(3), a5860. https://doi.org/10.4102/hts.v76i3.5860

Saltana, A.G., J. (2014). Extent and Background Factors of Physical and Mental Disability in Bangladesh. Dhaka University Journal of Science, 62(1):55-58. https://doi.org/10.3329/dujs.v62i1.21962

Sande, N. (2019). Towards inclusion: Disability and Indigenous Shona Culture in Zimbabwe. International Journal of Education and Social Science Research, 2(1): 1-12.

Sande, N. (2019a). Pastoral Ministry andPersons with Disabilities: The Case of the Apostolic Faith Mission in Zimbabwe. African Journal of Disability, 8(0);1-8. https://doi.org/10.4102/ajod.v8i0.431

Swinton, J. (2001). Spirituality and Mental Health Care. London: Jessica Kingsley Publishers.

Tongco, M. D. C. (2007). Purposive sampling as a tool for informant selection. Ethnobotany Research \& Applications, 5, 147-158. https://doi.org/10.17348/era.5.0.147-158

United Nations. (2006). Convention on the Rights of Persons with Disabilities. New York: United Nations.

Vermeer, D. (2014). Catholic Communications, Sydney Archdiocese. Recovered from: http://www.sydneycatholic. org/news/latest_news/2014/2014627_1055.shtml.

Warrington, K. (2008). Pentecostal Theology: A Theology of Encounter. London: T and T Clark.

World Health Organization. (2011). World Report on Disability 2011. Geneva: World Health Organization. https://doi.org/10.30875/b51b2f2c-en 